\title{
Florida Citrus Activity Book
}

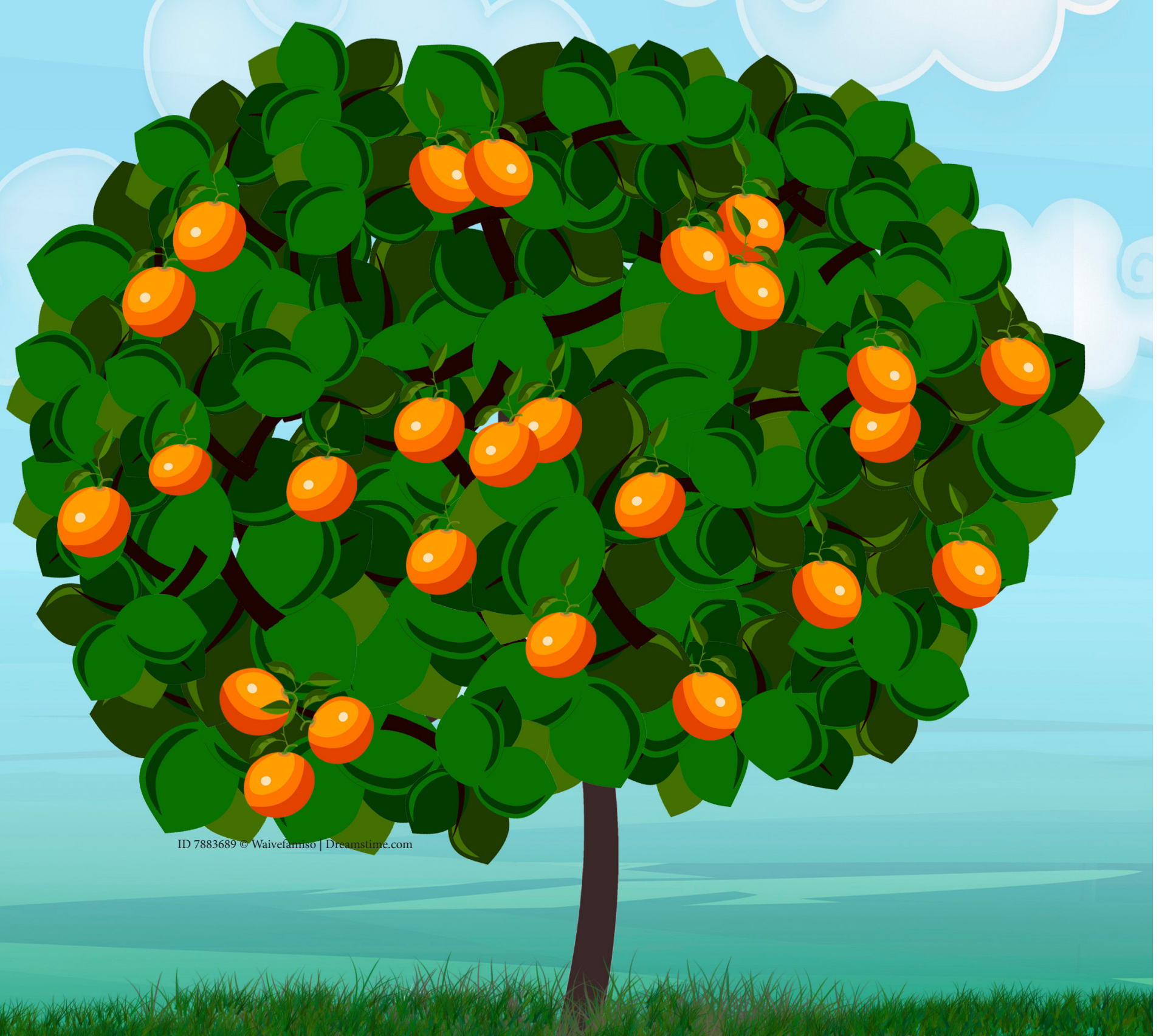

Provided by the UF/IFAS Citrus Research and Education Center 


\section{$\left.\mathbf{U F}\right|_{\text {UNIVERSITY of FLORDA }} ^{\text {IFAS Ex }}$}

\section{Created by J.D. Burrow, M.M. Dewdney,}

M.E. Rogers, and T. Vashisth

Cover Design by Kathy Snyder

UF/IFAS Citrus Research and Education Center

700 Experiment Station Road, Lake Alfred, Florida 33850

www.crec.ifas.ufl.edu

863.956.1151

The Institute of Food and Agricultural Sciences (IFAS) is an Equal Opportunity Institution authorized to provide research, educational information and other services only to individuals and institutions that function with non-discrimination with respect to race, creed, color, religion, age, disability, sex, sexual orientation, marital status, national origin, political opinions or affiliations. For more information on obtaining other UF/IFAS Extension publications, contact your county's UF/IFAS Extension office.

U.S. Department of Agriculture, UF/IFAS Extension Service, University of Florida, IFAS, Florida A \& M University Cooperative Extension Program, and Boards of County Commissioners Cooperating. Nick T. Place, dean for UF/IFAS Extension. 


\section{Parts of an Orange}

Directions: Color the parts of the orange.

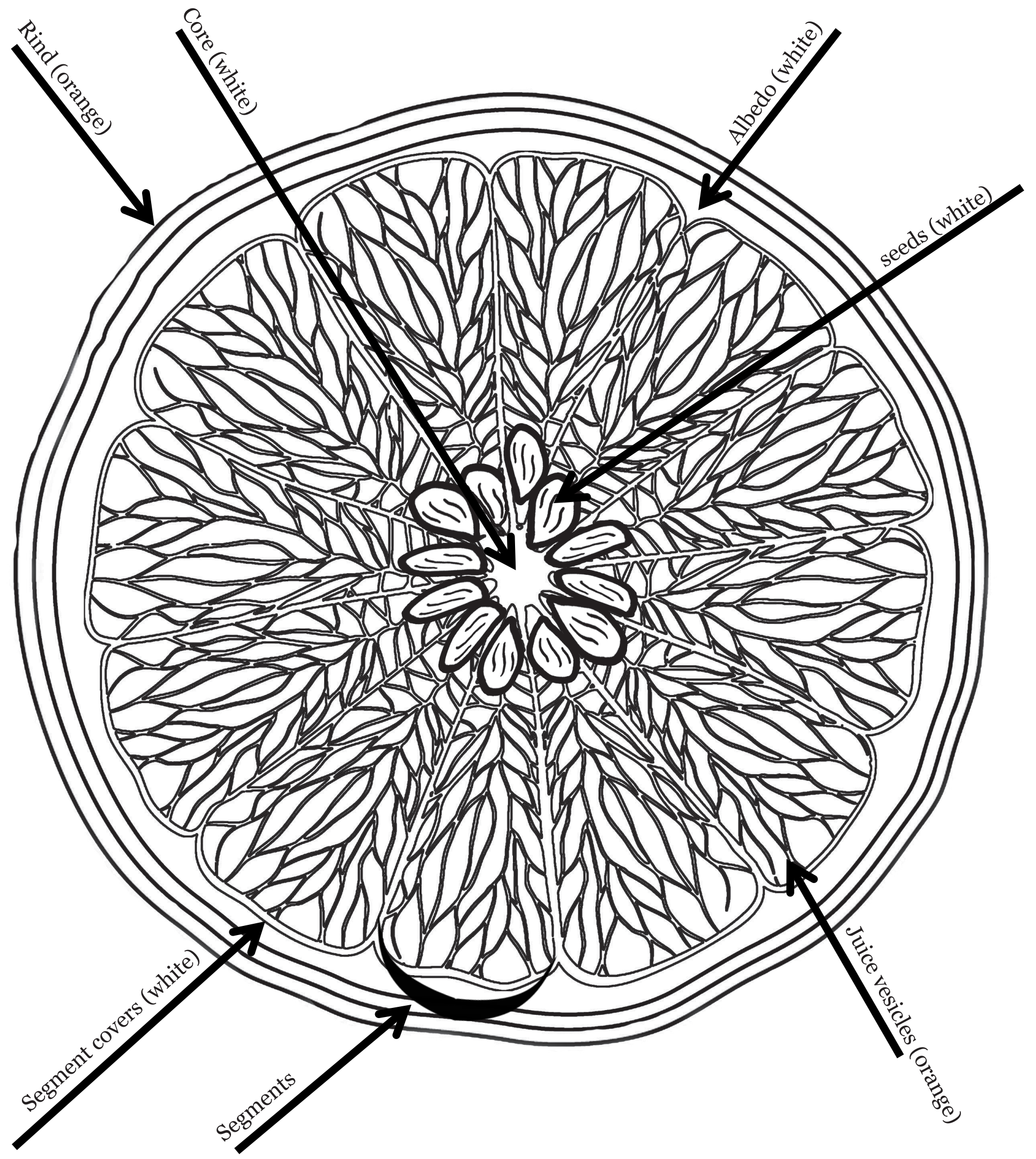

FUN FACT: Citrus fruit are modified berries. 


\section{Parts of a Citrus Leaf}

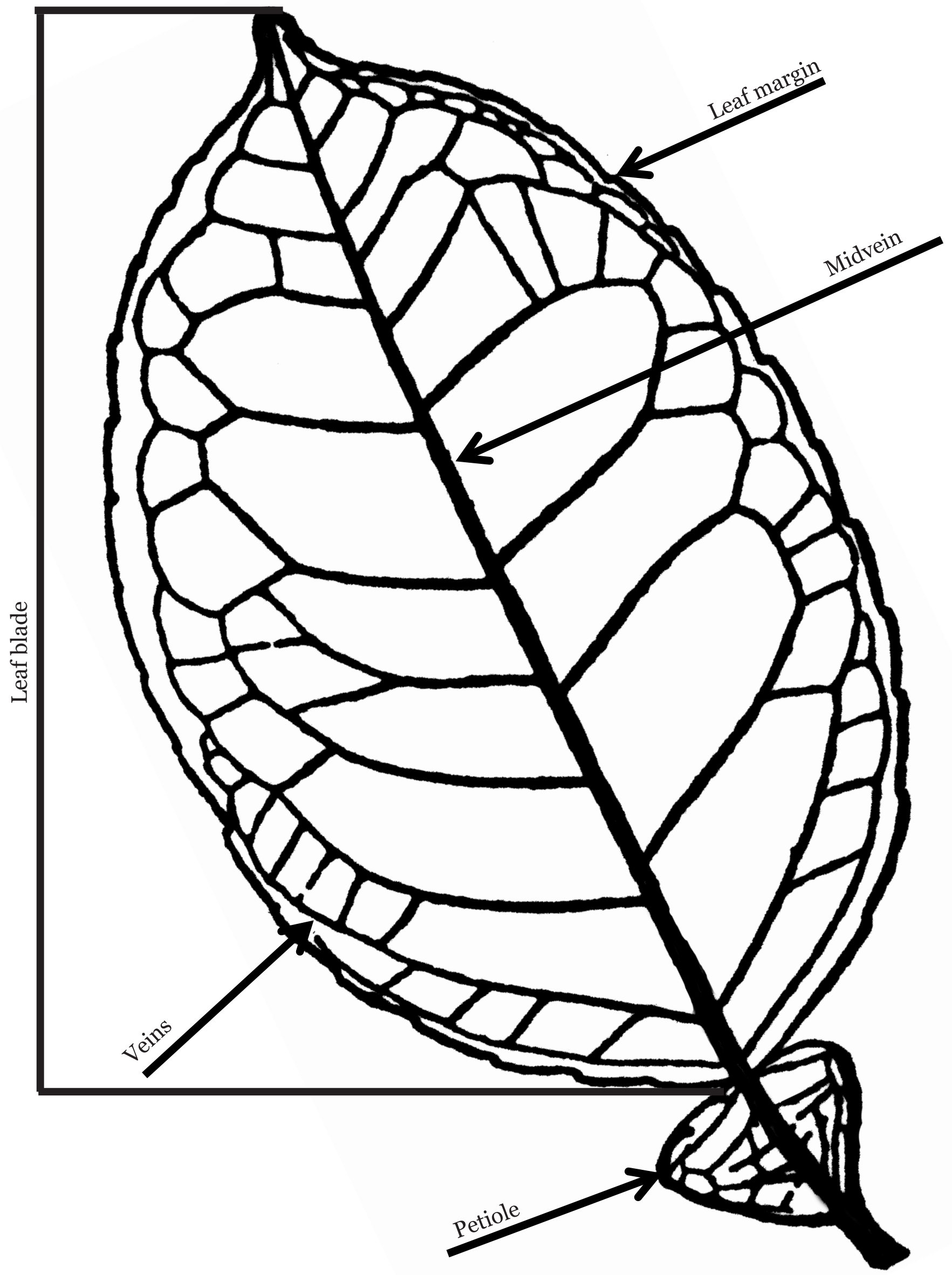

FUN FACT: Leaves are the primary site for food manufacturing in plants through the process called photosynthesis. Color the leaf green. 


\section{Parts of a Citrus Tree}

Directions: Label the parts of the tree and color.

$\begin{array}{llll}\text { Roots Leaves } & \text { Fruit } & \text { Trunk } & \text { Flower (Blossom) }\end{array}$
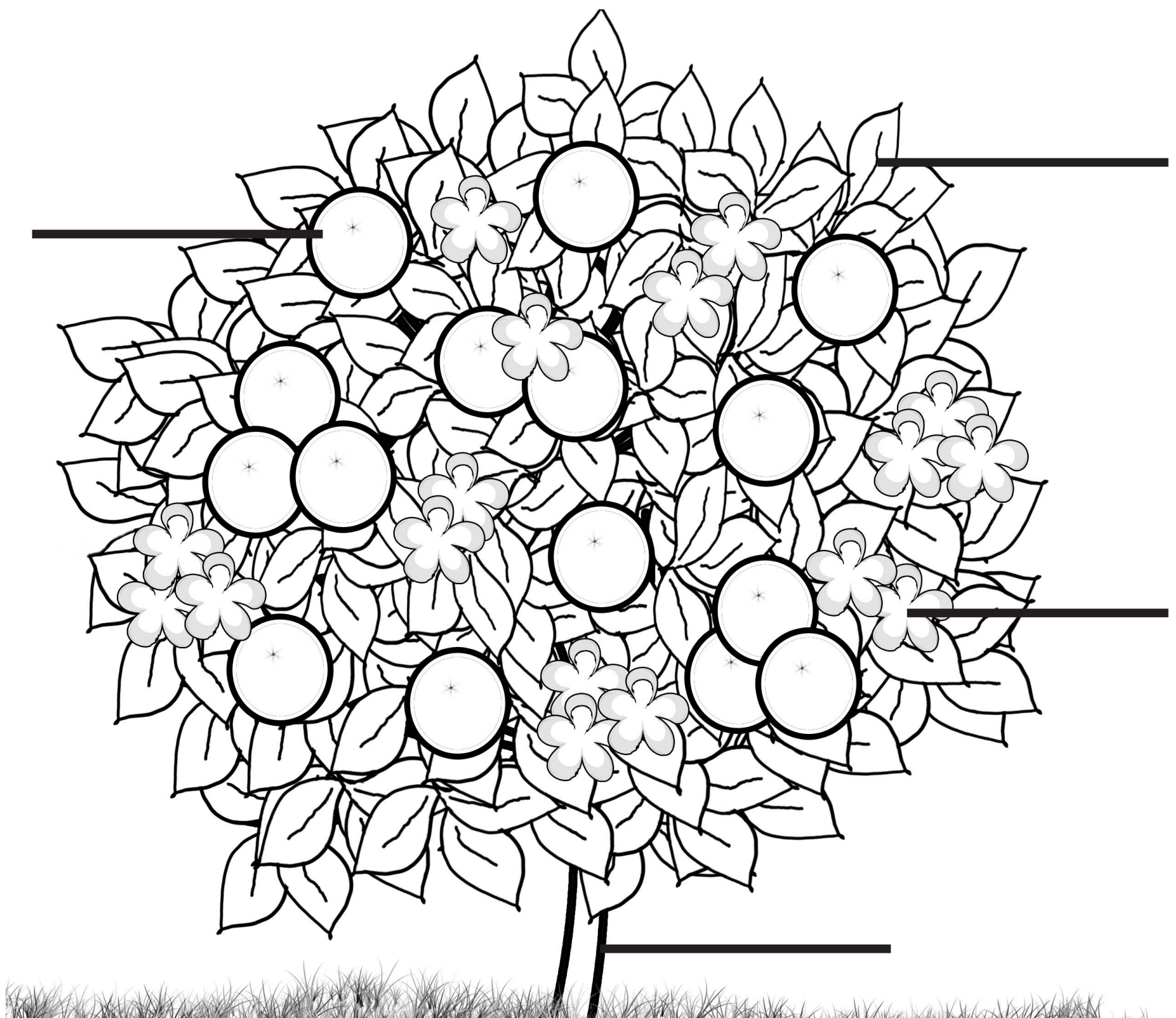

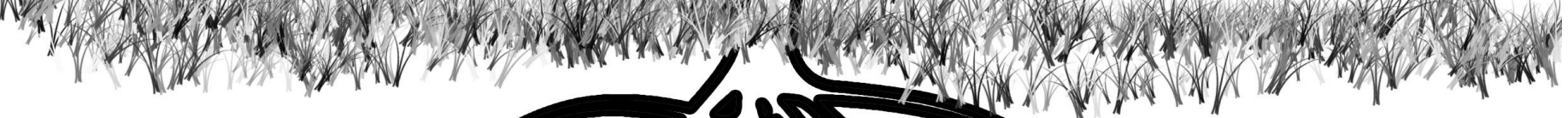

FUN FACT: Valencia orange is one of the few varieties that can carry 


\section{Citrus Varieties}

Below is a list of major Florida citrus varieties and their typical harvest period.

\section{Oranges}

Navel (October-January)

Hamlin (October-January)

Parson Brown (October-January)

Valencia (March-June)
Grapefruit

Duncan (December-May) Thompson (December-May)

Flame (November-May)

Ruby Red (November-May)
Lemons and Limes

Meyer Lemon (November-March)

Bearss Lemon (July-December)

Tahiti Lime (June-September) Key Lime (All year)

\section{Tangerines and Tangelos}

Murcott Tangerine (January-March) Sunburst Tangerine (November-December) Minneola Tangelo (December-February)

Satsuma (September-November)

\section{Miscellaneous}

Calamondin (November-April)

Nagami Kumquat (November-April)

Tavares Limequat (November-March)

Nakon Pummelo (December-February)

\section{DID YOU KNOW?}

- In Florida citrus, the term seedless means zero to six seeds. Although the Navel orange is considered seedless, you may find a few seeds.

- The Minneola Tangelo's nickname is the Honeybell because it is very sweet and in the shape of a bell.

- The majority of Florida's oranges are squeezed into juice.

- Grapefruit from Florida is shipped to Japan by boat.

- You can eat an entire Kumquat, even the peel.

- Satsuma is one of the earliest tangerine varieties and grows best in north Florida.
Directions: Count the number of seeds in the orange.

Number of seeds:

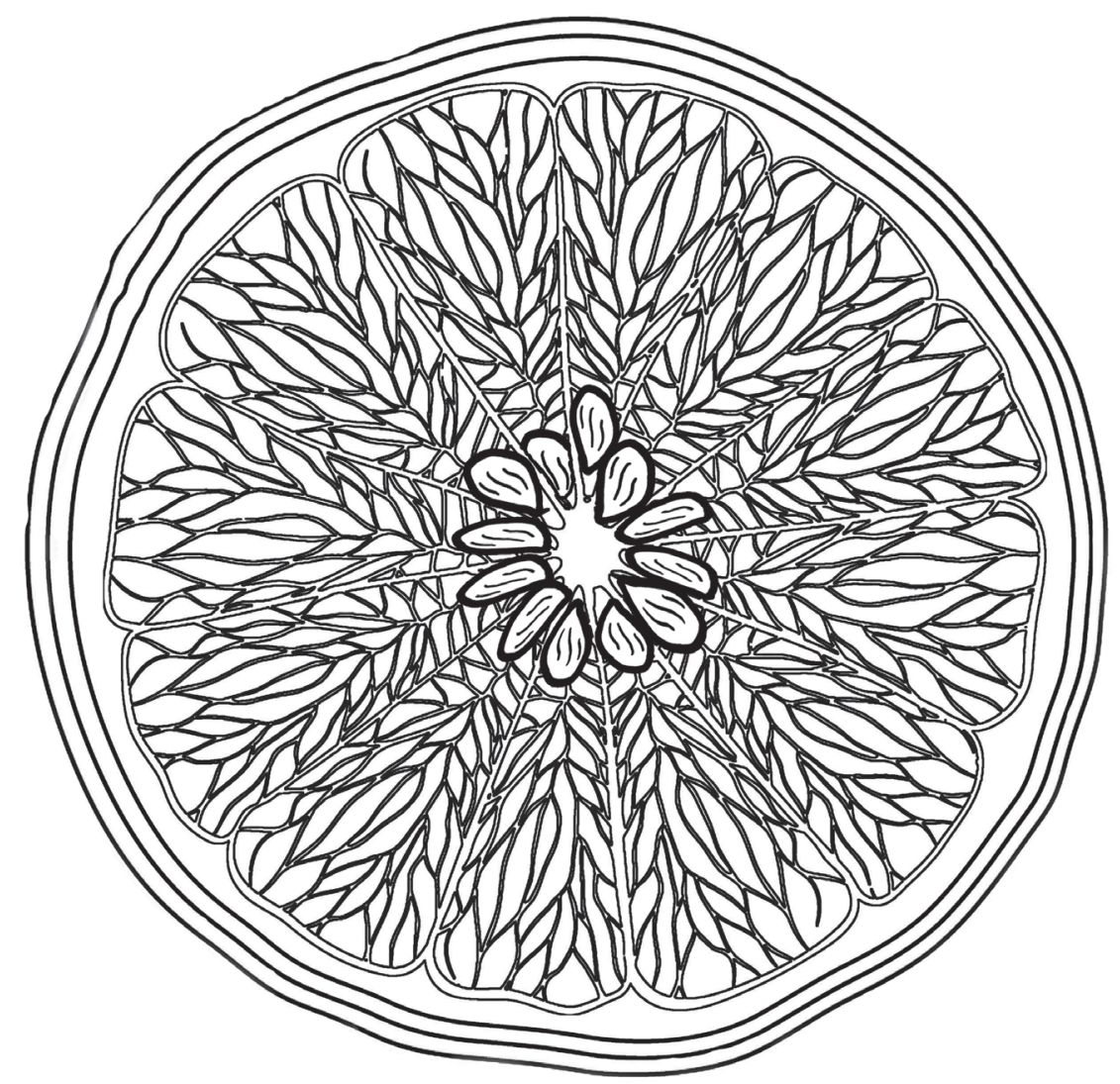

What is your favorite citrus fruit? 


\section{Citrus Diseases}

Citrus trees can get sick just like people. There are three causes of diseases: fungi, bacteria, and viruses.

\section{Bacterial Diseases}

Citrus Canker

Citrus Greening

\section{Fungal Diseases}

Greasy Spot

Citrus Scab

Alternaria Brown Spot

Melanose

Citrus Black Spot

Phytophthora Root Rot

Brown Rot

\section{Viral Diseases}

Tristeza

Exocortis

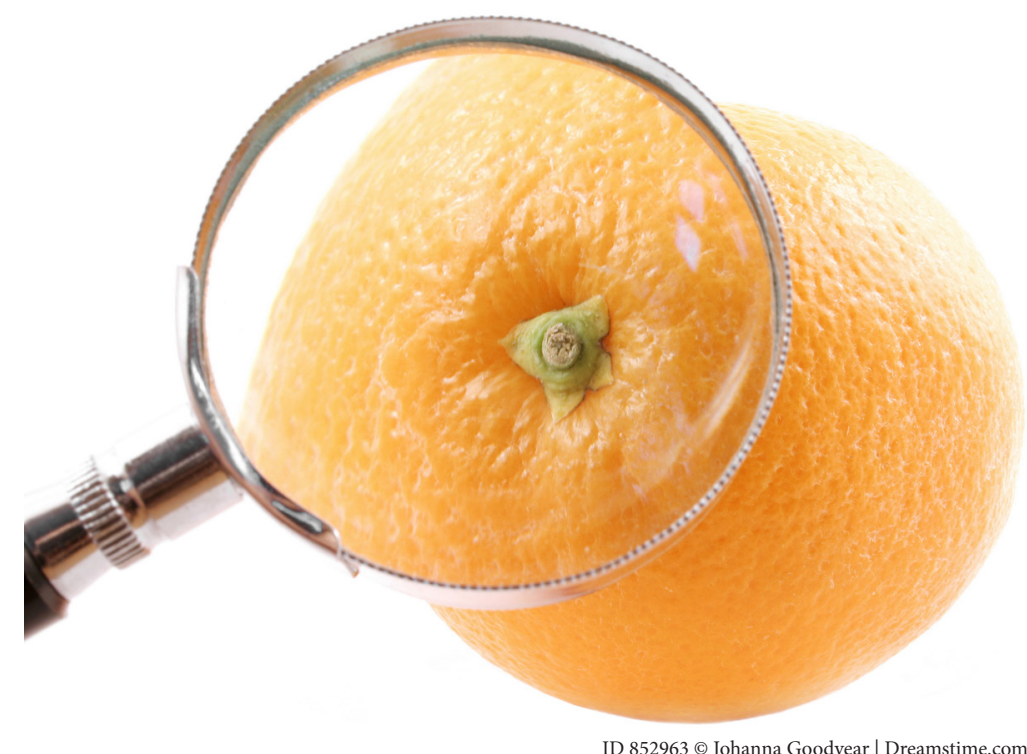

Directions: Below is a list of common citrus diseases. Using the lists above, identify their cause of disease. Write "B" for bacterial, " $F$ " for fungal, and "V" for viral.

Exocortis

Brown Rot

Citrus Black Spot

Citrus Canker

Citrus Greening

Citrus Scab
Alternaria Brown Spot

Greasy Spot

Melanose

Phytophthora Root Rot

Tristeza 


\section{Citrus Canker}

Citrus canker is a very contagious disease for citrus trees. It does not harm people. It makes oranges, grapefruit, lemons, and tangerines look very bad. Although it is not pretty on the outside, you can still eat the fruit.

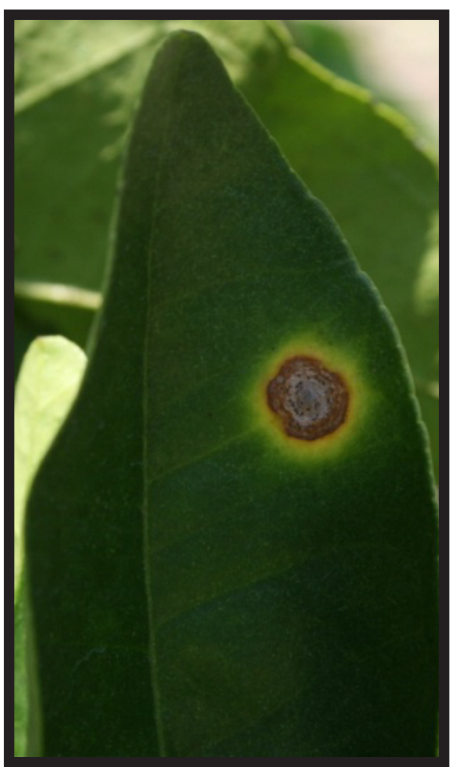

Citrus canker

lesions (spots) are

usually tan when

first formed. As the

lesions get older,

they form a yellow

circle around the tan

lesion. This is called a

yellow halo or yellow

ring. You can see the

same symptoms on

both leaves and fruit.

The yellow halo is

commonly seen when

identifying canker.

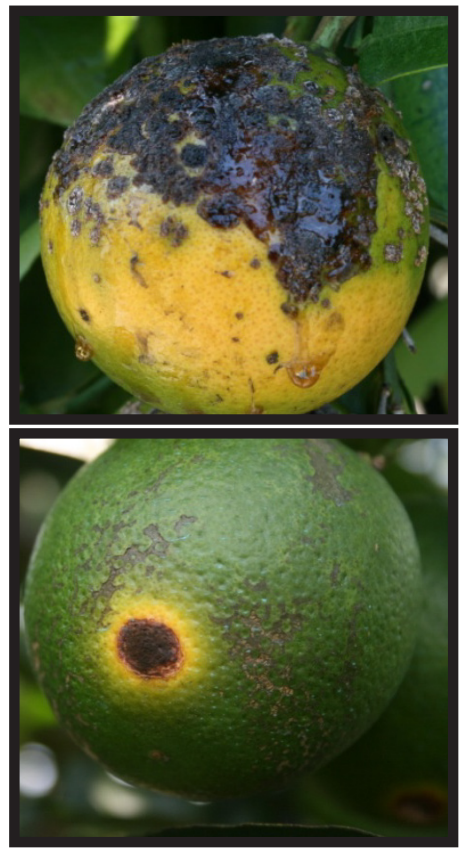

The lesions feel rough and are raised. They are not smooth like the leaf. As the lesions get older, they turn dark brown to black. You can sometimes see a sticky substance oozing out of the lesion. This is where the bacteria lives and, when the wind blows, it spreads the bacteria.

Color By Number

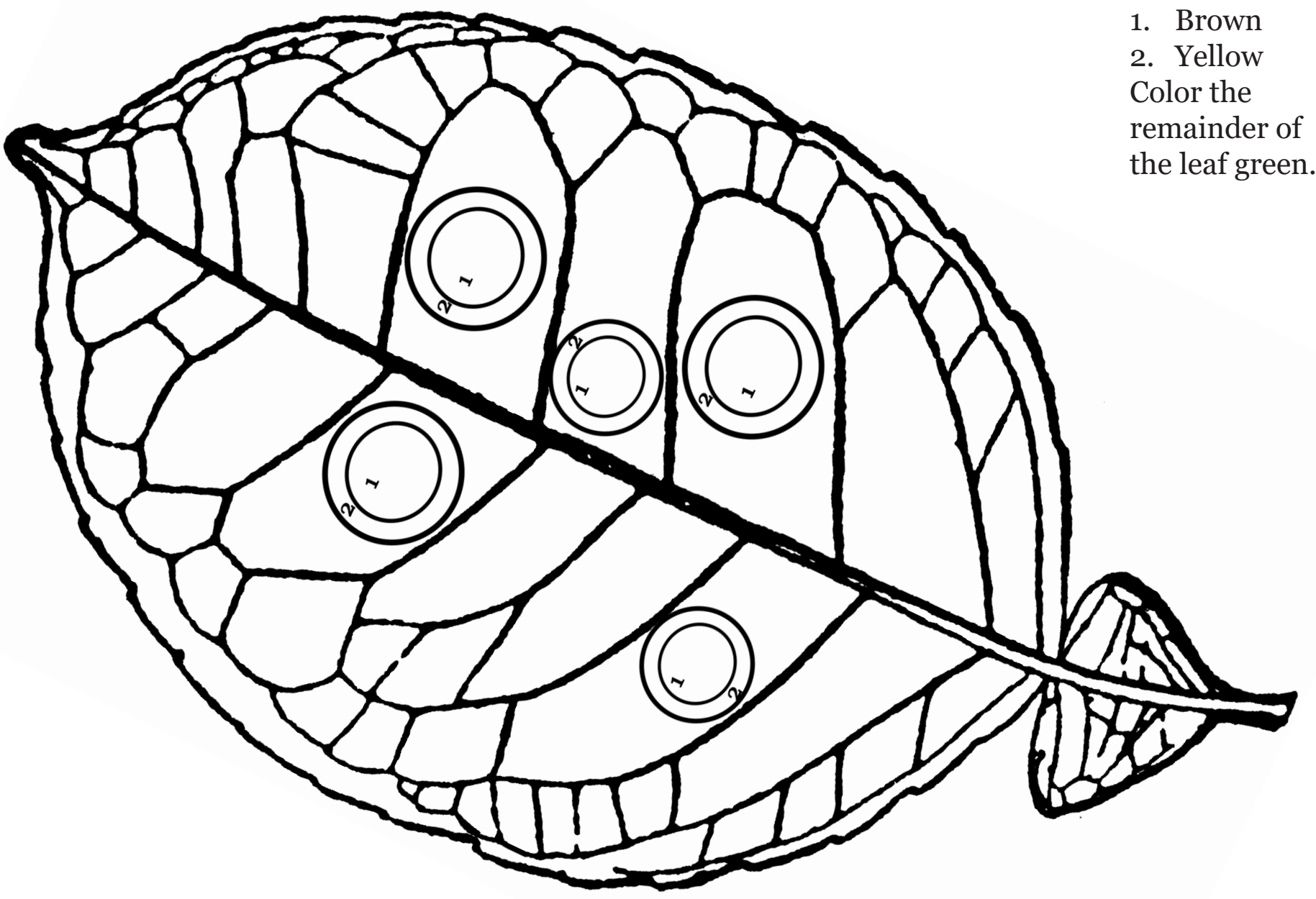




\section{Citrus Black Spot}
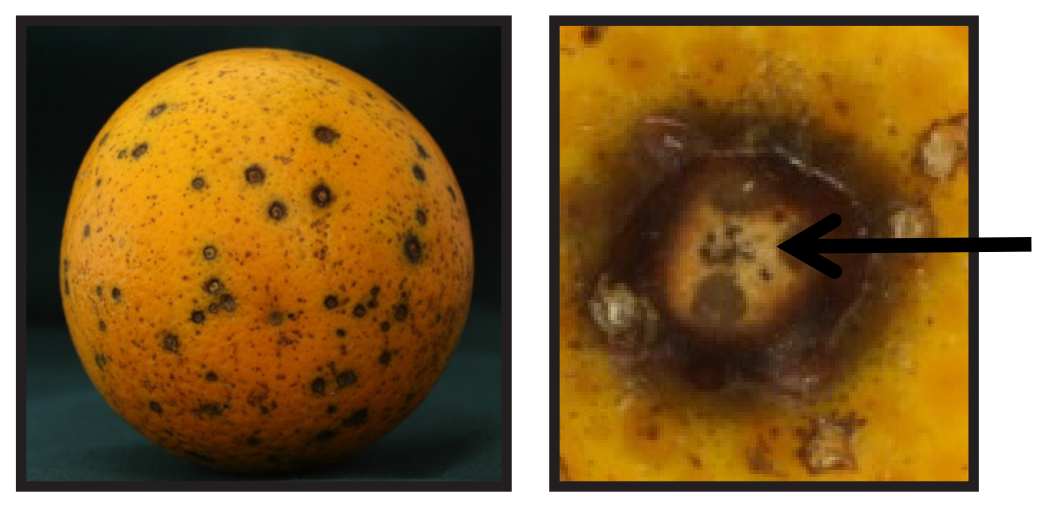

Citrus black spot is a fungal disease that causes various types of spots on the fruit. The most common type is hard spot. It is round and sunken. If you look inside the circle, you can see little dots. The little dots are the fungal structures.

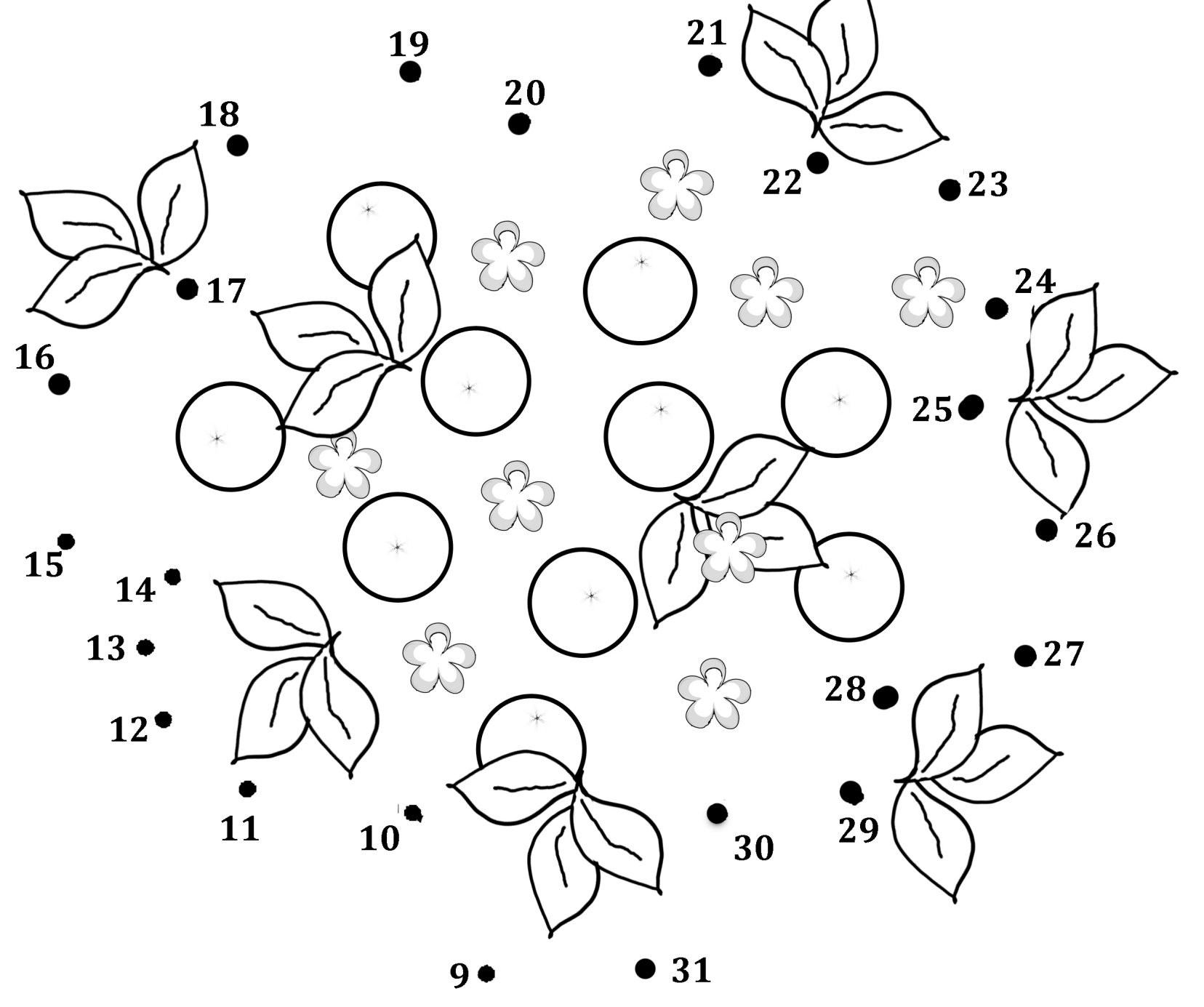

Directions: Connect the dots and color the picture.

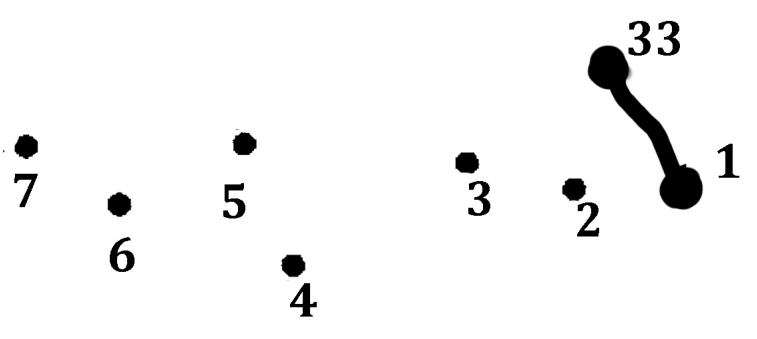




\section{Fungal Diseases}

Fungal diseases reproduce well in moist and humid conditions. Florida has the perfect conditions for fungal diseases. The most common fungal diseases are greasy spot, scab, melanose, and alternaria. Citrus fruit infected by fungal diseases may look bad, but it does not harm the inside of the fruit. You can still eat the fruit!

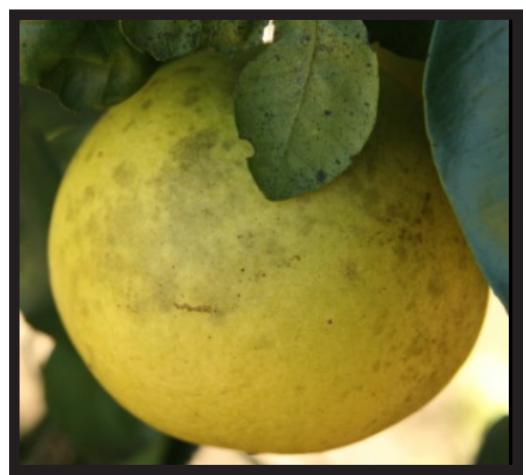

Greasy Spot

Looks like dust on fruit surface

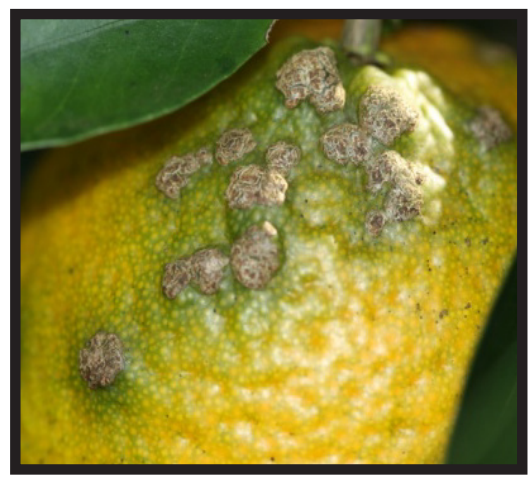

Citrus Scab

Looks like warts

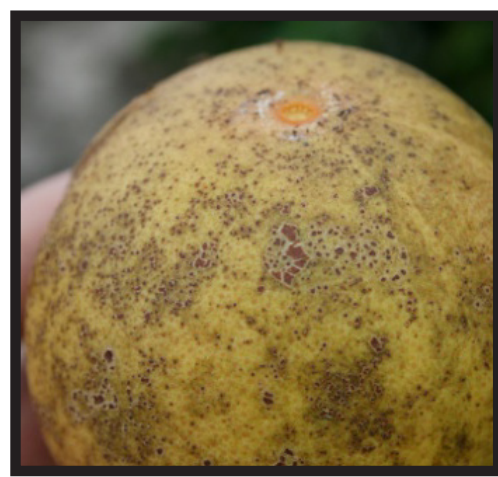

Melanose

Feels like sandpaper

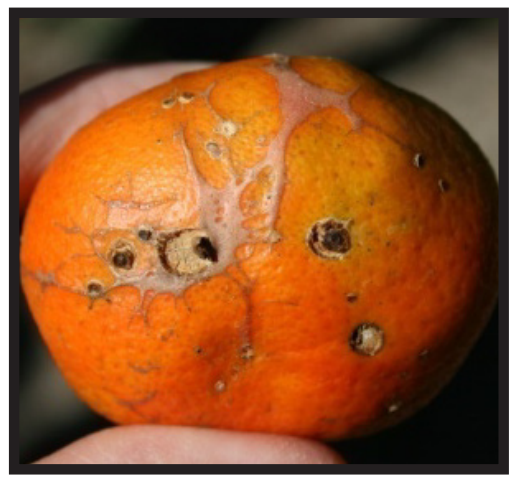

Alternaria Brown Spot

Looks like craters

Directions: Fill in the crossword puzzle with the common citrus fungal diseases found in Florida.

\section{Greasy Spot}

D

$\mathbf{I}$

$\mathbf{S}$

$\mathbf{E}$

A

$\mathbf{S}$

$\mathbf{E}$
Scab

Melanose

Alternaria 


\section{Citrus Greening}

Citrus greening is a bacterial disease. Its official name is Huanglongbing (HLB). The leaf symptoms have a blotchy mottle pattern. It causes fruit to be lopsided and small; the rind does not color properly. The fruit may taste bitter and sour. It affects oranges, grapefruit, tangerines, tangelos, lemons, and limes-all citrus varieties!

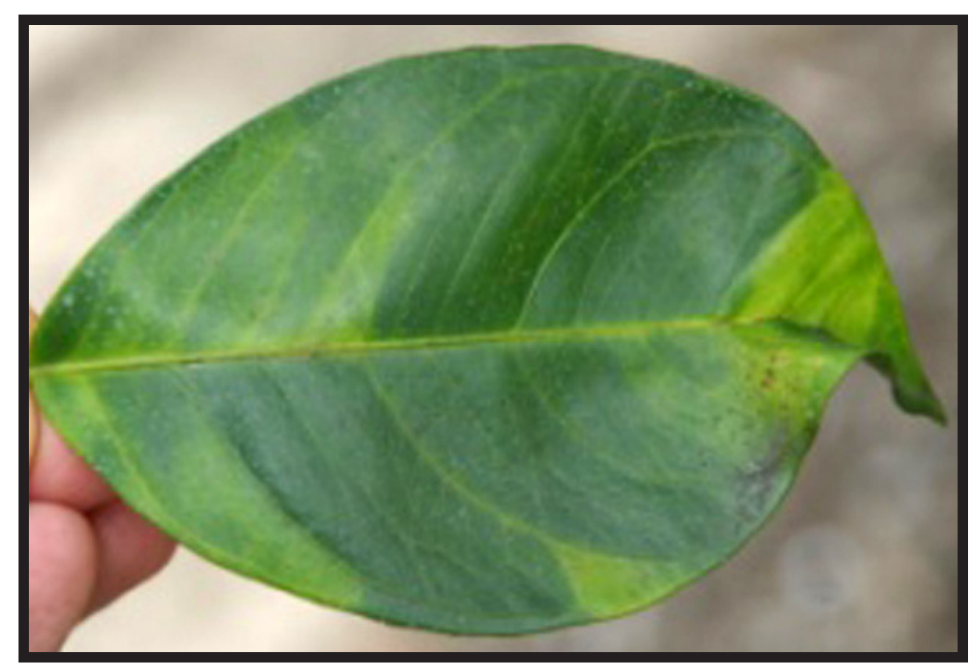

Blotchy mottle pattern

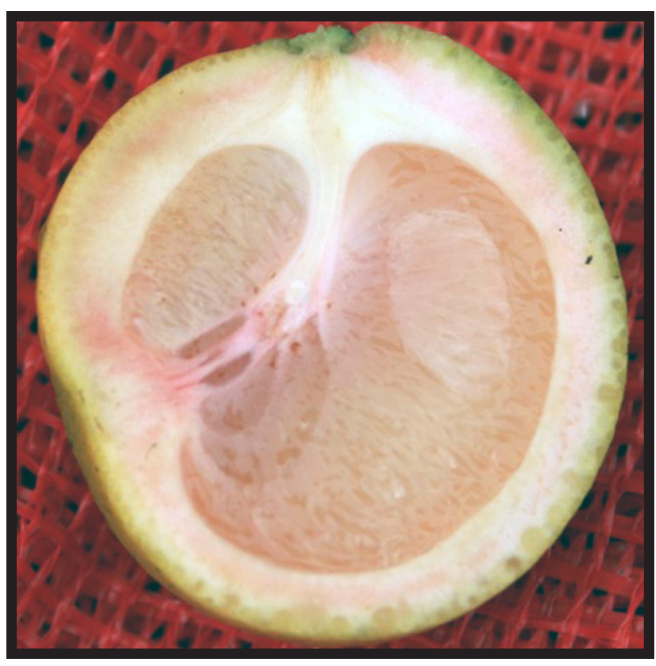

The curved central core inside of a grapefruit

Directions: Circle the words in the puzzle below.

BACTERIA

GRAPEFRUIT

HUANGLONGBING

ORANGES
CITRUS

GREENING

LOPSIDED

PHLOEM
FRUIT

HLB

MISSHAPEN

PSYLLID

SMALL

TANGERINES

\begin{tabular}{|c|c|c|c|c|c|c|c|c|c|c|c|c|}
\hline$S$ & G & $\mathrm{R}$ & $B$ & $\mathrm{~T}$ & L & $\mathrm{F}$ & $B$ & $E$ & $G$ & Z & $M$ & $\mathrm{~T}$ \\
\hline$U$ & $A$ & $\mathrm{~N}$ & $G$ & $\mathrm{~L}$ & C & $\mathrm{N}$ & $\mathrm{G}$ & $B$ & 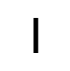 & $\mathrm{N}$ & $G$ & A \\
\hline C & I & I & $S$ & 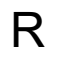 & $S$ & $P$ & $X$ & $\mathrm{~J}$ & $\mathrm{M}$ & $F$ & & 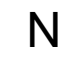 \\
\hline D & I & $X$ & $\mathrm{R}$ & ᄃ & A & W & $A$ & 1 & $\mathrm{~T}$ & - & $\mathrm{R}$ & \\
\hline $\mathrm{L}$ & $\mathrm{J}$ & $\mathrm{T}$ & $G$ & & $\mathrm{R}$ & $P$ & $S$ & $\mathrm{M}$ & L & & & \\
\hline $\mathrm{L}$ & $\mathrm{T}$ & $\mathrm{N}$ & $\mathrm{R}$ & 1 & $\mathrm{~T}$ & $S$ & $E$ & V & $\mathrm{M}$ & $\mathrm{H}$ & $X$ & $R$ \\
\hline $\mathrm{R}$ & $A$ & I & $R$ & $U$ & $\mathrm{H}$ & C & 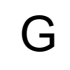 & $\pi$ & $\mathrm{K}$ & & K & \\
\hline $\mathrm{R}$ & $\mathrm{Q}$ & $\mathrm{R}$ & $F$ & $A$ & $\mathrm{~S}$ & $\mathrm{G}$ & $A$ & $S$ & $\mathrm{R}$ & $\mathrm{H}$ & M & $\mathrm{N}$ \\
\hline$X$ & U & $\mathrm{R}$ & $\mathrm{F}$ & $\mathrm{C}$ & $E$ & $\mathrm{M}$ & 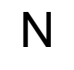 & $B$ & U & $U$ & $\mathrm{M}$ & \\
\hline $\mathrm{F}$ & $U$ & $E$ & $G$ & $\Lambda$ & I & $\mathrm{N}$ & $E$ & $\mathrm{E}$ & $\mathrm{R}$ & $\mathrm{G}$ & I & 5 \\
\hline I & $\mathrm{N}$ & $P$ & $S$ & $\mathrm{r}$ & $\mathbf{L}$ & $\mathrm{L}$ & 1 & D & B & L & 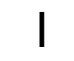 & $\Gamma$ \\
\hline L & $\mathrm{L}$ & $A$ & $\mathrm{M}$ & $\mathrm{S}$ & $\mathrm{V}$ & $\mathrm{R}$ & V & $\mathrm{M}$ & $\mathrm{P}$ & $L$ & $Y$ & \\
\hline U & $A$ & $X$ & Z & r & $T$ & $\mathrm{M}$ & I & $\mathrm{K}$ & $E$ & $\mathrm{~V}$ & $\mathrm{H}$ & 0 \\
\hline$M$ & W & $\mathrm{N}$ & $x$ & $B$ & $G$ & $E$ & $\mathrm{~T}$ & I & $G$ & $A$ & $A$ & VI \\
\hline$Q$ & V & 0 & D & 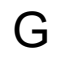 & $\mathrm{N}$ & $F$ & $\mathrm{~K}$ & W & $\mathrm{P}$ & $\mathrm{N}$ & $A$ & $\mathrm{R}$ \\
\hline
\end{tabular}




\section{Asian Citrus Psyllid}

The Asian citrus psyllid is the insect responsible for spreading the bacteria that causes citrus greening. It is a small insect, about 3-4 millimeters in length (smaller than a grain of rice).

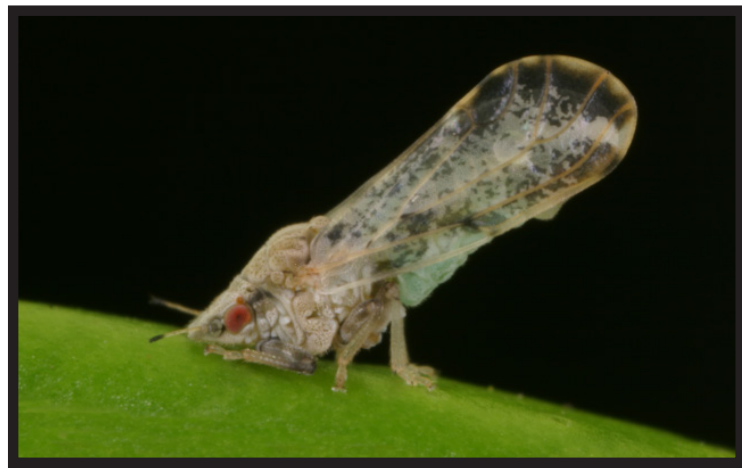

The female psyllid lays the eggs on the new flush (new leaves) of citrus trees. It takes about 14 days for the eggs to hatch. The psyllid nymphs then go through 5 stages before becoming an adult.

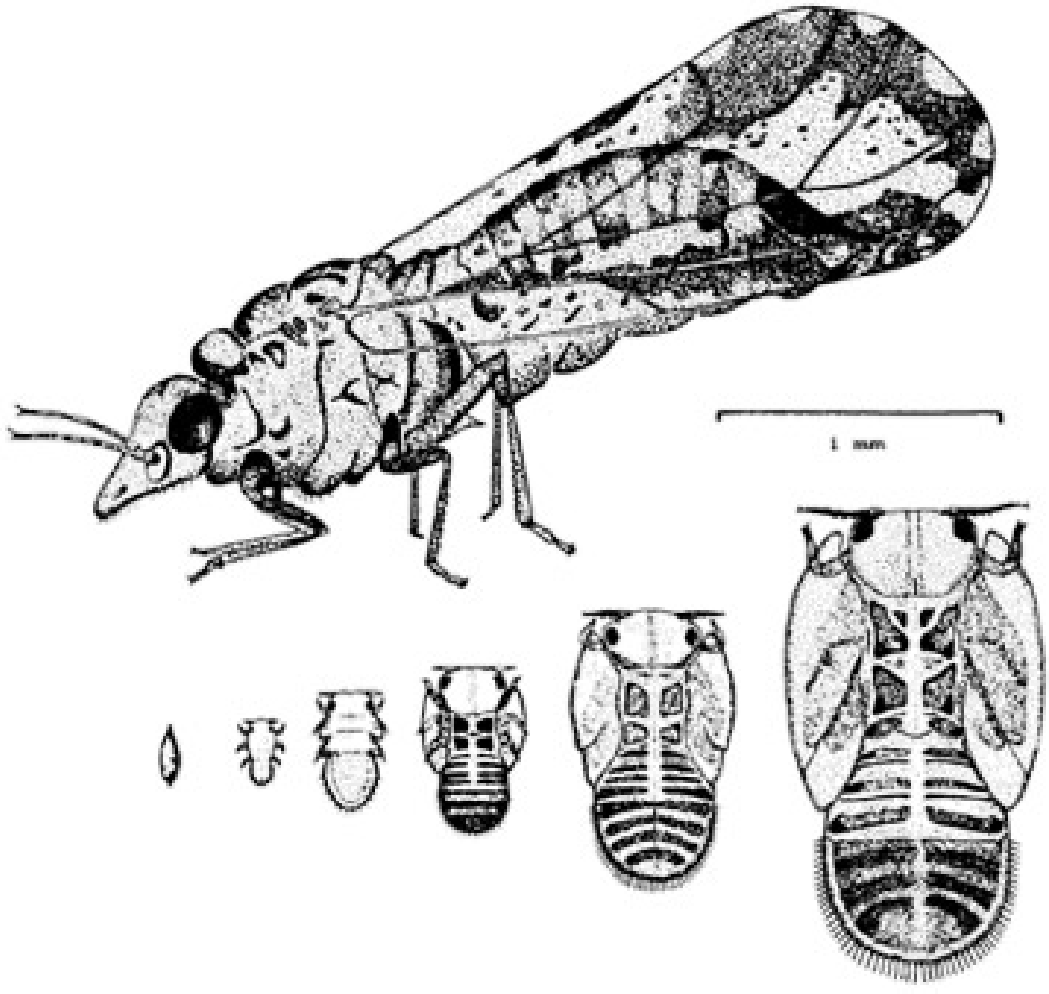

Psyllid egg and the 5 nymph stages

Directions: Connect the dots to complete the psyllid's wings.

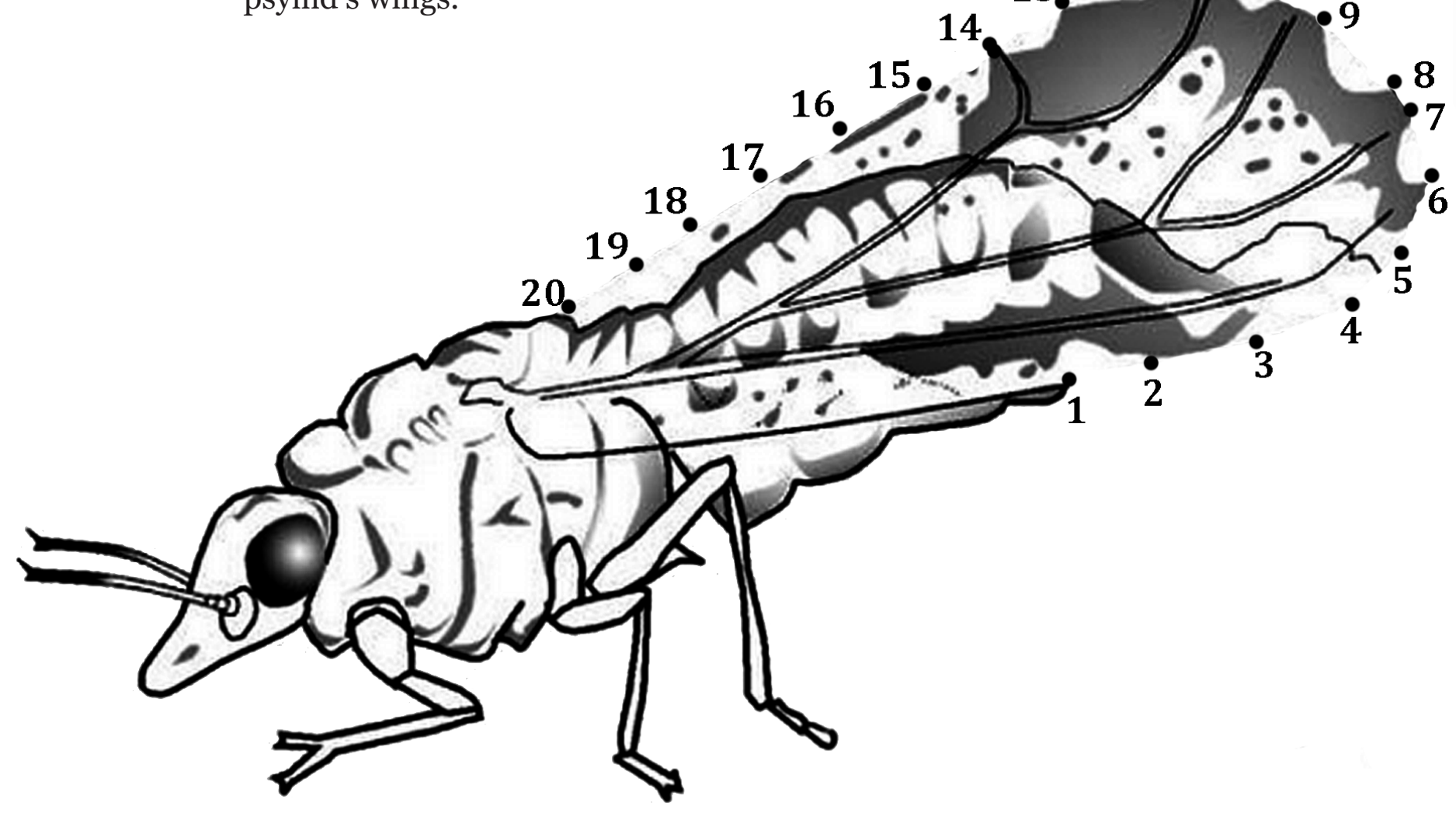




\section{Citrus Leafminer}

Leafminer is a very small moth, but the larvae stage can cause severe damage on citrus leaves. The larvae tunnels underneath the leaf's skin (cuticle), eating the nutrients. It then grows while leaving a trail before finally emerging as an adult.
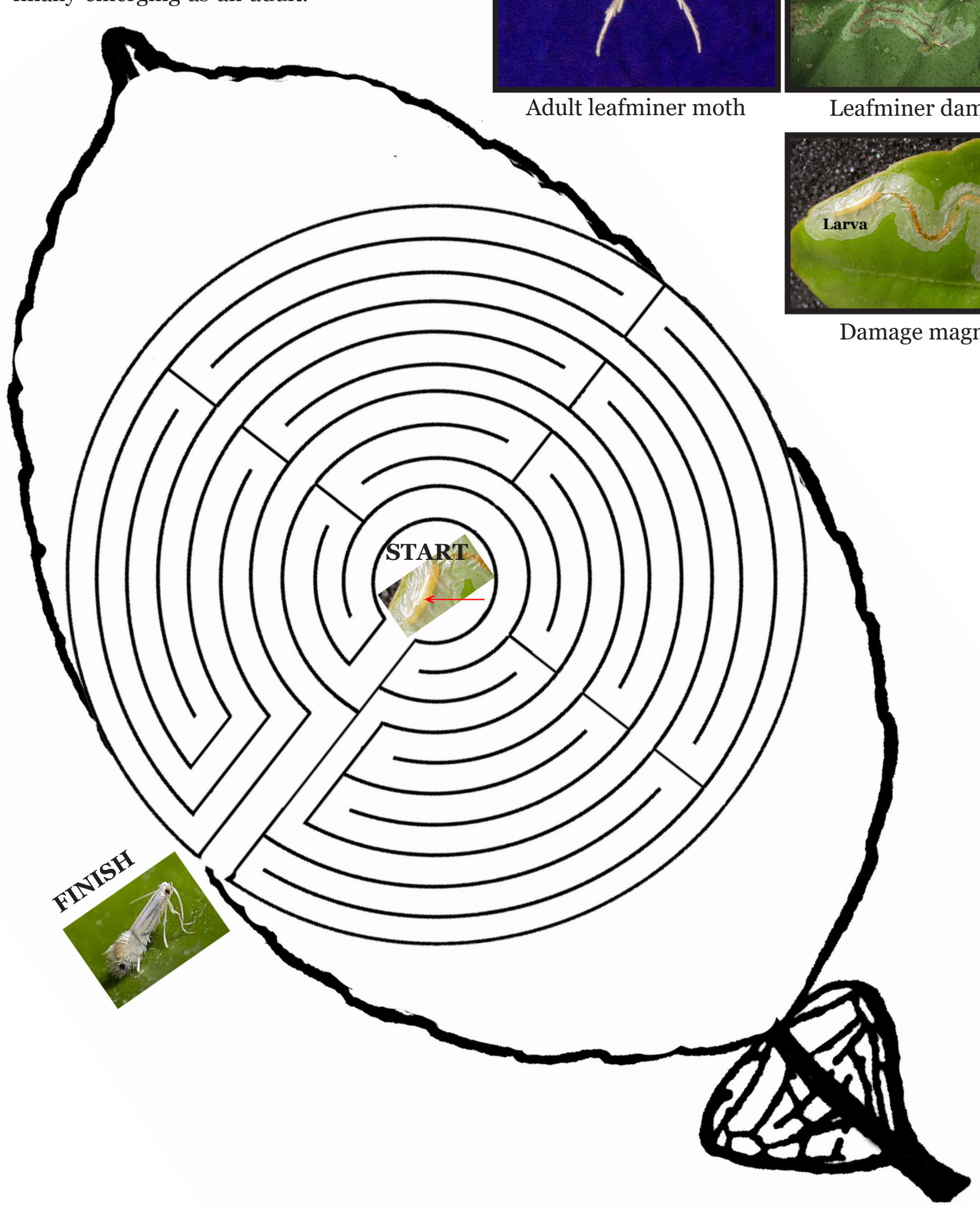

Directions: From start (larvae) to finish (adult moth), help the larvae grow into an adult. 


\section{Weeds}

Citrus pests and diseases play a major role in citrus care but weeds compete for water, nutrients, sunlight, and space for growth; therefore, weeds are an important part of plant care too. Weeds act as substitute hosts of insect pests and diseases. Weeds are super abundant seed producers; some weeds such as Spanishneedles can produce as many as 5,000 seeds per plant per year! Weeds reproduce through seeds or through sprouting from rhizomes, stolons, and bulbs found under the soil. Weeds can be a grass, a broadleaf, or a sedge.

\begin{tabular}{|c|c|c|c|c|c|c|c|c|c|c|c|c|c|c|c|c|c|c|c|c|c|c|c|c|c|}
\hline A & B & C & D & E & F & G & H & I & J & K & L & M & N & O & P & Q & R & S & T & U & V & W & X & Y & Z \\
\hline $\mathbf{1}$ & $\mathbf{2}$ & $\mathbf{3}$ & $\mathbf{4}$ & $\mathbf{5}$ & $\mathbf{6}$ & $\mathbf{7}$ & $\mathbf{8}$ & $\mathbf{9}$ & $\mathbf{1 0}$ & $\mathbf{1 1}$ & $\mathbf{1 2}$ & $\mathbf{1 3}$ & $\mathbf{1 4}$ & $\mathbf{1 5}$ & $\mathbf{1 6}$ & $\mathbf{1 7}$ & $\mathbf{1 8}$ & $\mathbf{1 9}$ & $\mathbf{2 0}$ & $\mathbf{2 1}$ & $\mathbf{2 2}$ & $\mathbf{2 3}$ & $\mathbf{2 4}$ & $\mathbf{2 5}$ & $\mathbf{2 6}$ \\
\hline
\end{tabular}

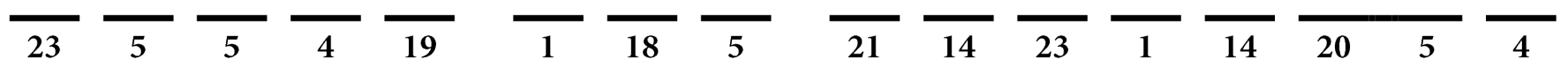

Directions: Using the key above, complete the statement by matching the numbers and filling in the corresponding letter.

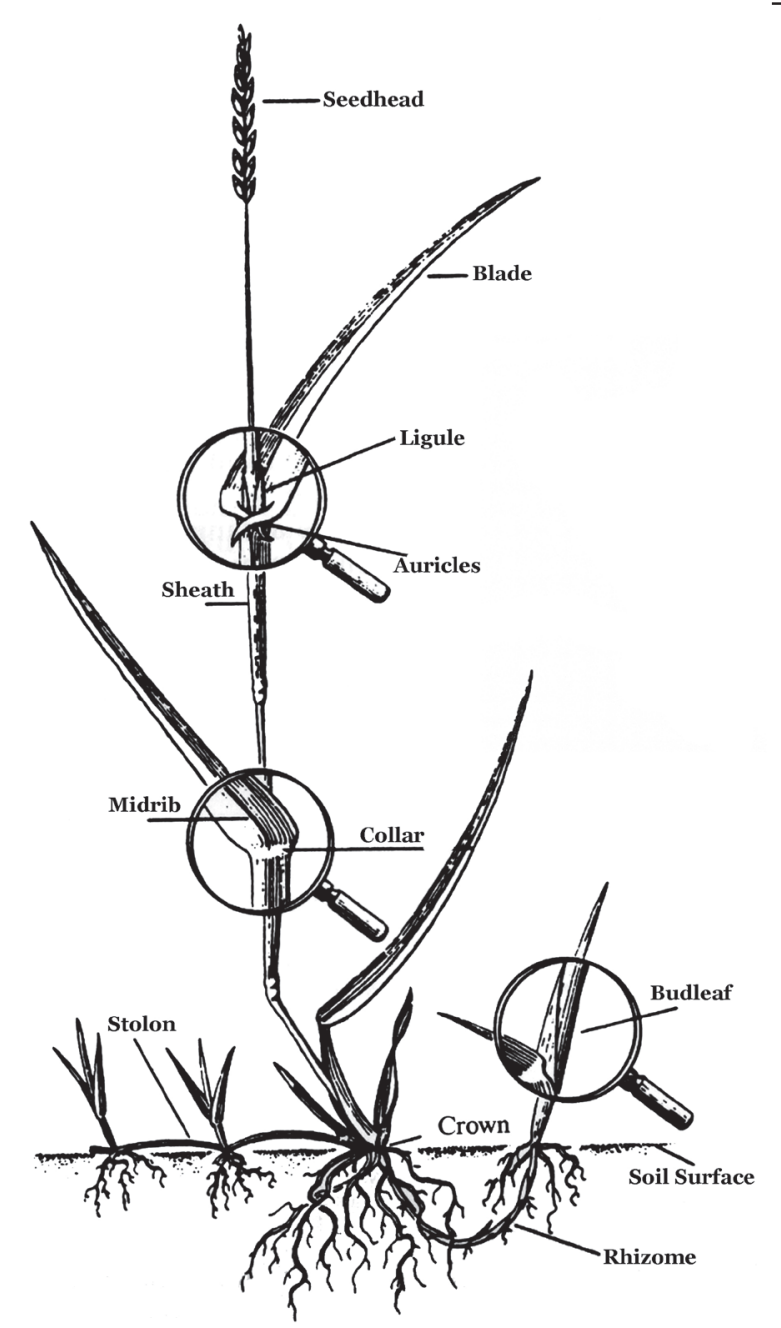

\section{Parts of Weeds}

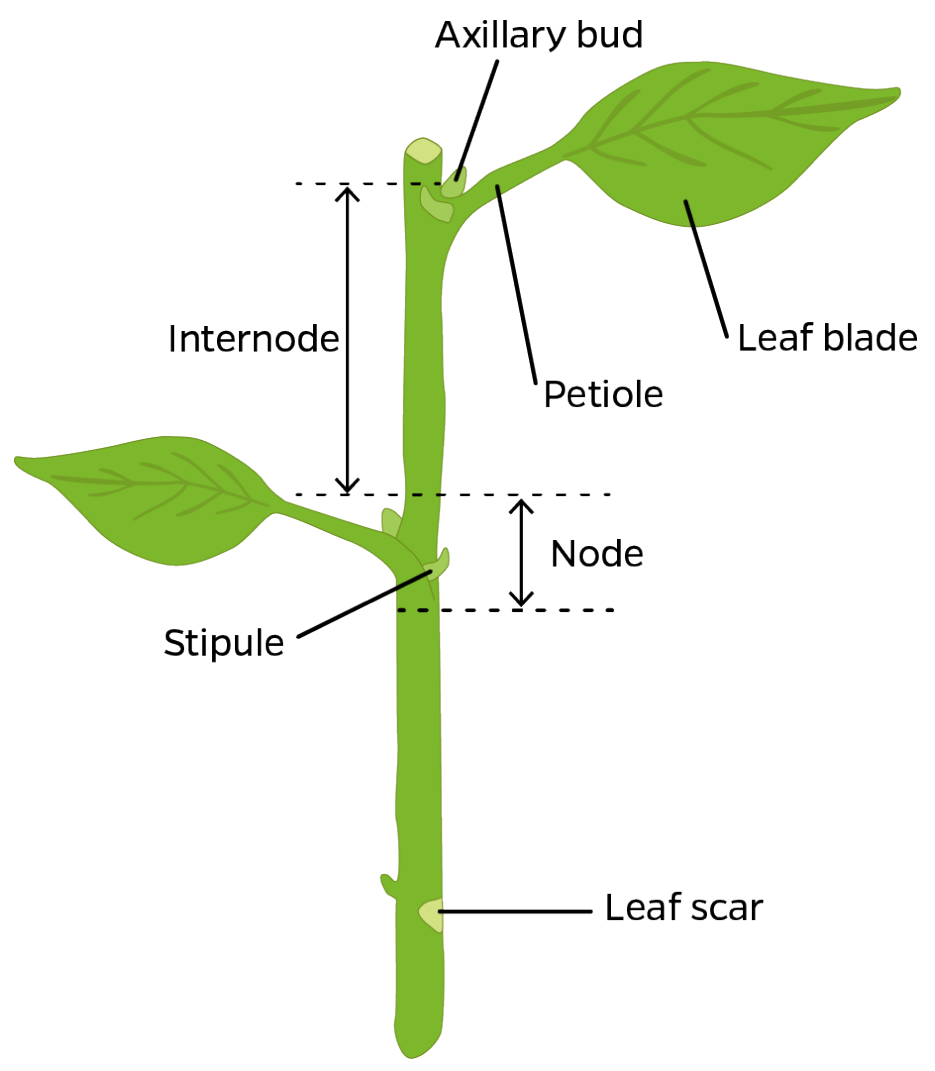




\section{Recipes}

Always remember to check with an adult before starting!

\section{Honey Grapefruit Delight}

\section{Ingredients}

$2 \quad$ Florida grapefruit

2 tablespoons honey

3 tablespoons sliced toasted almonds

\section{Yogurt Sauce:}

1 cup nonfat plain yogurt

2 tablespoons honey

$1 / 4 \quad$ teaspoon grated grapefruit peel

$1 / 4$ teaspoon almond extract

\section{Steps}

1. Peel and slice grapefruit into $1 / 2$ " thick rounds.

2. In a large bowl, combine grapefruit and honey; toss lightly to coat.

3. Cover and chill until ready to serve.

4. In a small bowl, mix sauce ingredients; stir well.

5. Divide grapefruit slices among 4 individual dishes.

6. Top with yogurt sauce; sprinkle with almonds.

Serves 4 .

\section{Florida Sunshine Shake}

\section{Ingredients}

1 cup orange juice

$1 / 2$ cup grapefruit juice

1 ripe banana

$1 / 2$ cup lowfat vanilla yogurt

$1 / 2$ teaspoon vanilla

\section{Steps}

Combine all ingredients in a blender until smooth. Pour into glasses and serve immediately.

Makes two 8-ounce servings.

\section{Orange Tango}

\section{Ingredients}

$3 / 4$ cup frozen orange juice concentrate, thawed

2 large mangos peeled and chopped or two 8 ounce bags chunked frozen mango

2 cups lemon sherbet

$1^{1 / 2}$ cups milk or almond milk

1 teaspoon vanilla

\section{Steps}

1. In a blender, combine thawed concentrate and mango chunks.

2. Cover and blend until mixture is smooth.

3. Add sherbet, milk, and vanilla.

4. Cover and blend until smooth.

Pour into glasses and serve immediately.

Makes five 8-ounce servings.

\section{Orange Juice Cake}

\section{Ingredients}

1 package (2 layer size) yellow cake mix

1 4-ounce package lemon instant pudding mix

4 eggs

$3 / 4 \quad$ cup corn oil

$3 / 4$ cup orange juice

\section{Steps}

1. Combine the cake mix, pudding mix, eggs, corn oil, and orange juice in a mixing bowl.

2. Beat at low speed for 2 minutes, scraping the bowl constantly.

3. Spoon the batter into a greased and floured tube pan or $9 \times 13$-inch cake pan.

4. Bake in preheated 325 degree oven for 45 minutes.

5. Cool completely before frosting or enjoy without.

Makes 10 servings. 
Page 5

\section{Answer Key}

Page 9

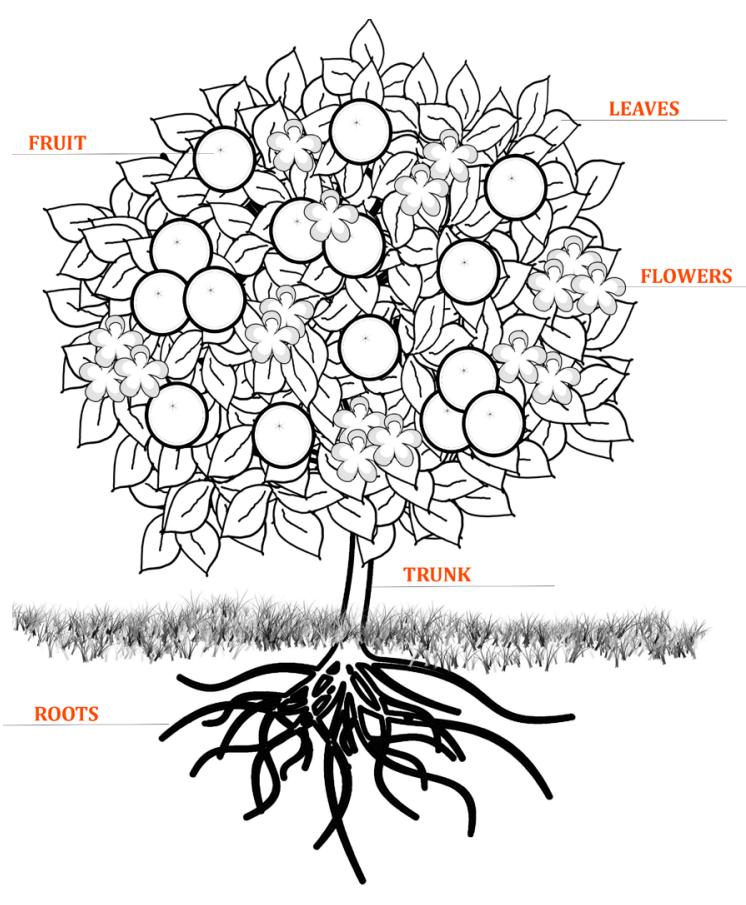

Page 6

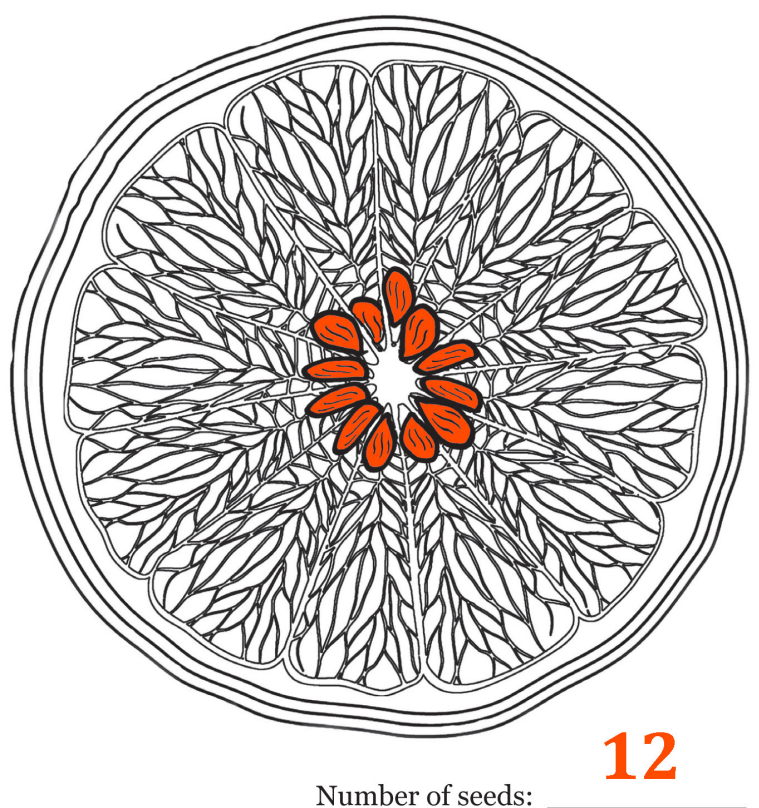

Page 7

\begin{tabular}{|c|c|c|c|}
\hline $\mathbf{V}$ & Exocortis & $\mathbf{F}$ & Alternaria Brown Spot \\
\hline $\mathbf{F}$ & Brown Rot & $\mathbf{F}$ & Greasy Spot \\
\hline$F$ & Citrus Black Spot & $F$ & Melanose \\
\hline B & Citrus Canker & $\mathbf{F}$ & Phytophthora Root Rot \\
\hline B & Citrus Greening & $\mathrm{V}$ & Tristeza \\
\hline $\mathbf{F}$ & Citrus Scab & & \\
\hline
\end{tabular}

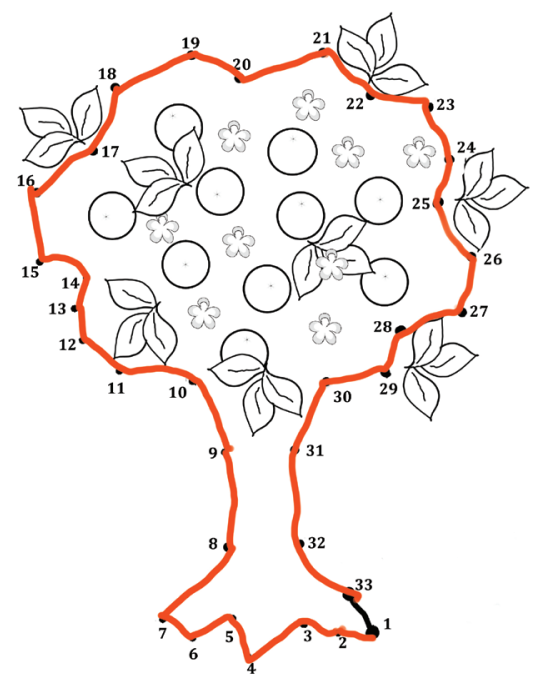

Page 10

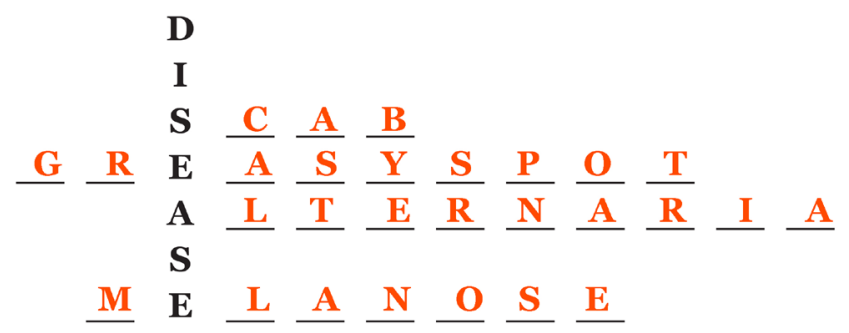

Page 11

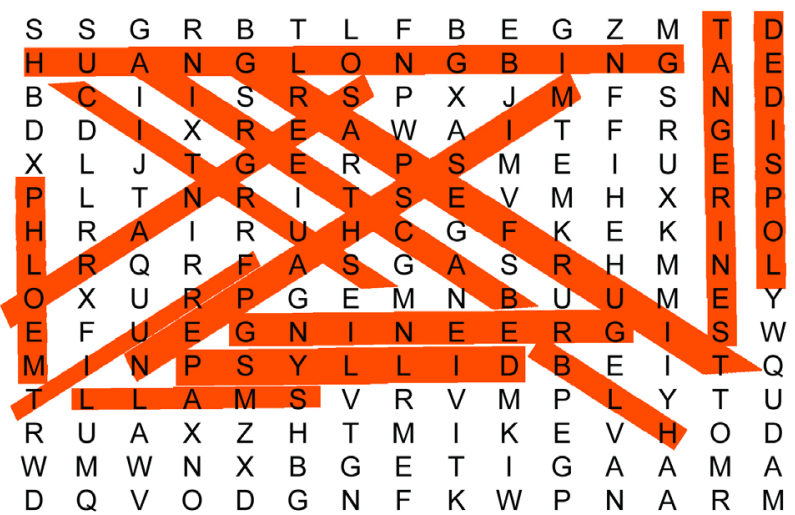




\section{Answer Key}

Page 12

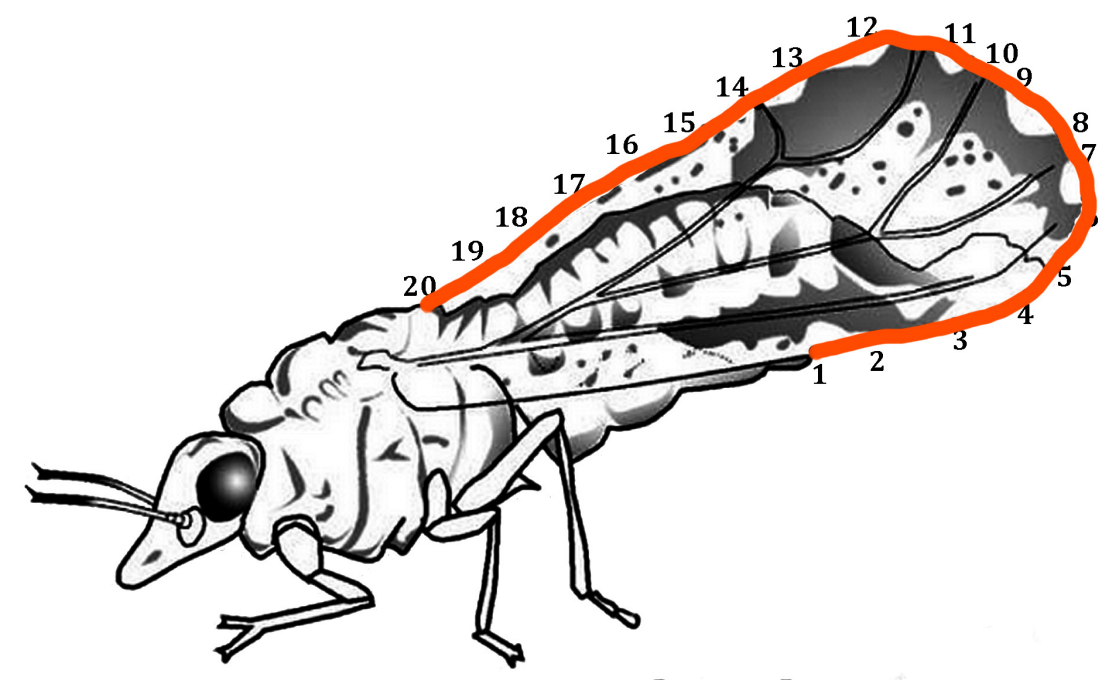

Page 13

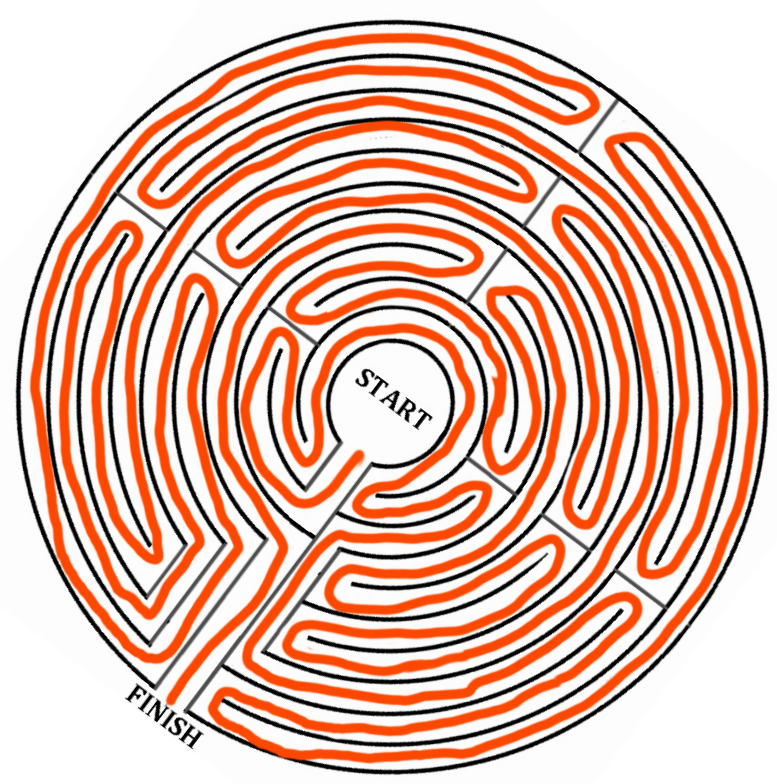

Page 14

\begin{tabular}{rl|c|c|c|c|c|c|c|c|c|c|c|c|c|c|c|c|c|c|c|c|c|c|c|c|c|}
\hline A & B & C & D & E & F & G & H & I & J & K & L & M & N & O & P & Q & R & S & T & U & V & W & X & Y & Z \\
\hline 1 & 2 & 3 & 4 & 5 & 6 & 7 & 8 & 9 & 10 & 11 & 12 & 13 & 14 & 15 & 16 & 17 & 18 & 19 & 20 & 21 & 22 & 23 & 24 & 25 & 26 \\
\hline
\end{tabular}




\section{Photo Credits}

\section{Front Cover Page}

Trunk and roots with grass Katherine M. Snyder, UF/IFAS CREC

Background DigitalJuice Canvases Vol. 4 'Picket Fence'

Oranges DigitalJuice Juice Drops No. 31 Food Fusion 3104_JuiceDrop

Leaves ID 7883689 (C) Waivefamiso|Dreamstime.com

\section{Page 3}

Orange Traced image Digital Juice, Juice Drops No. 31 Food Fusion 3175_JuiceDrop

Seeds Katherine M. Snyder, UF/IFAS CREC

\section{Page 4}

Leaf Copyright @ 2004-2016 Florida Center for Instructional Technology. ClipArt ETC is a part of the Educational Technology Clearinghouse and is produced by the Florida Center for Instructional Technology, College of Education, University of South Florida. http://etc.usf.edu/ clipart/58500/58557/58557_grpfrt_leaf.htm

\section{Page 5}

Tree (leaves, fruit, trunk, roots, and grass) Katherine M. Snyder, UF/IFAS CREC

Blossoms ID 24195949 (c) Dannyphoto80|Dreamstime. com

\section{Page 6}

Question mark ID 30493170 (C) Alexyndr|Dreamstime. com

Orange Traced image Digital Juice, Juice Drops No. 31 Food Fusion 3175_JuiceDrop

Seeds Katherine M. Snyder, UF/IFAS CREC

Page 7

Orange with lens ID 852963 (C) Johanna Goodyear|Dreamstime.com

\section{Page 8}

Canker leaf and fruits Jamie D. Burrow, UF/IFAS CREC

Leaf Copyright (c) 2004-2016 Florida Center for Instructional Technology. ClipArt ETC is a part of the Educational Technology Clearinghouse and is produced by the Florida Center for Instructional Technology, College of Education, University of South Florida. http://etc.usf.edu/ clipart/58500/58557/58557_grpfrt_leaf.htm.

Simulated canker lesions (circles) on leaf Katherine M. Snyder, UF/IFAS CREC

\section{Page 9}

Citrus black spot Megan M. Dewdney, UF/IFAS CREC

Tree outline (leaves, fruit, and trunk) Katherine M. Snyder, UF/IFAS CREC

Blossoms ID 24195949 (C) Dannyphoto80|Dreamstime. com

\section{Page 10}

Greasy spot Megan M. Dewdney, UF/IFAS CREC Citrus scab Megan M. Dewdney, UF/IFAS CREC Melanose Jamie D. Burrow, UF/IFAS CREC Alternaria Jamie D. Burrow, UF/IFAS CREC

\section{Page 11}

Blotchy mottle pattern UF/IFAS CREC

HLB infected grapefruit Jamie D. Burrow, UF/IFAS CREC

\section{Page 12}

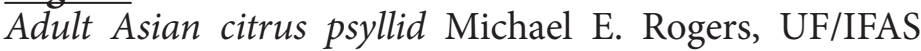
CREC

Adult female and nymphal instars of Asian citrus psyllid Drawing by Division of Plant Industry. http:// entnemdept.ufl.edu/creatures/citrus/acpsyllid.htm

Connect the dot activity Drawing by Division of Plant Industry. http://entnemdept.ufl.edu/creatures/citrus/ acpsyllid.htm. Modified by Katherine M. Snyder, UF/ IFAS CREC

\section{Page 13}

Adult leafminer moth Photograph by Jeffery W. Lotz, Florida Department of Agriculture and Consumer Services, Division of Plant Industry. http://entnemdept.ufl.edu/ creatures/citrus/citrus_leafminer.htm

Leafminer damage UF/IFAS CREC

Leafminer damage magnified UF/IFAS CREC

Magnified larva (maze starting point) UF/IFAS CREC

Adult leafminer moth (maze finishing point) Photo by Jack Kelly Clark http://cisr.ucr.edu/citrus_leafminer.html

Leaf Copyright ( $2004-2016$ Florida Center for Instructional Technology. ClipArt ETC is a part of the Educational Technology Clearinghouse and is produced by the Florida Center for Instructional Technology, College of Education, University of South Florida. http://etc.usf.edu/ clipart/58500/58557/58557_grpfrt_leaf.htm. Modified by Katherine M. Snyder, UF/IFAS CREC

\section{Page 14}

Grass weed North Carolina State University. https://content. ces.ncsu.edu/extension-gardener-handbook/6weeds\#section_heading_7497

Broadleaf weed UF/IFAS Communications

\section{Page 15}

Honey Grapefruit Delight recipe FDOC FG0002 10/98 IMM, Honey \& Florida Grapefruit - Sweet \& Healthy (brochure)

Florida Sunshine Shake Florida Department of Citrus, 1998

Orange Tango Florida Department of Citrus, 1998

Orange Juice Cake Simply Florida: A taste of Flavors from the Sunshine State, Florida Extension Association of Family and Consumer Sciences, University of Florida, Gainesville, 2007, pg. 121

\section{Back Cover Page}

Trunk and roots with grass Katherine M. Snyder, UF/IFAS CREC

Background DigitalJuice Canvases Vol. 4 'Picket Fence'

Oranges DigitalJuice Juice Drops No. 31 Food Fusion 3104_JuiceDrop

Leaves ID 7883689 ( ) Waivefamiso|Dreamstime.com 



\section{Eat Florida Citrus!}

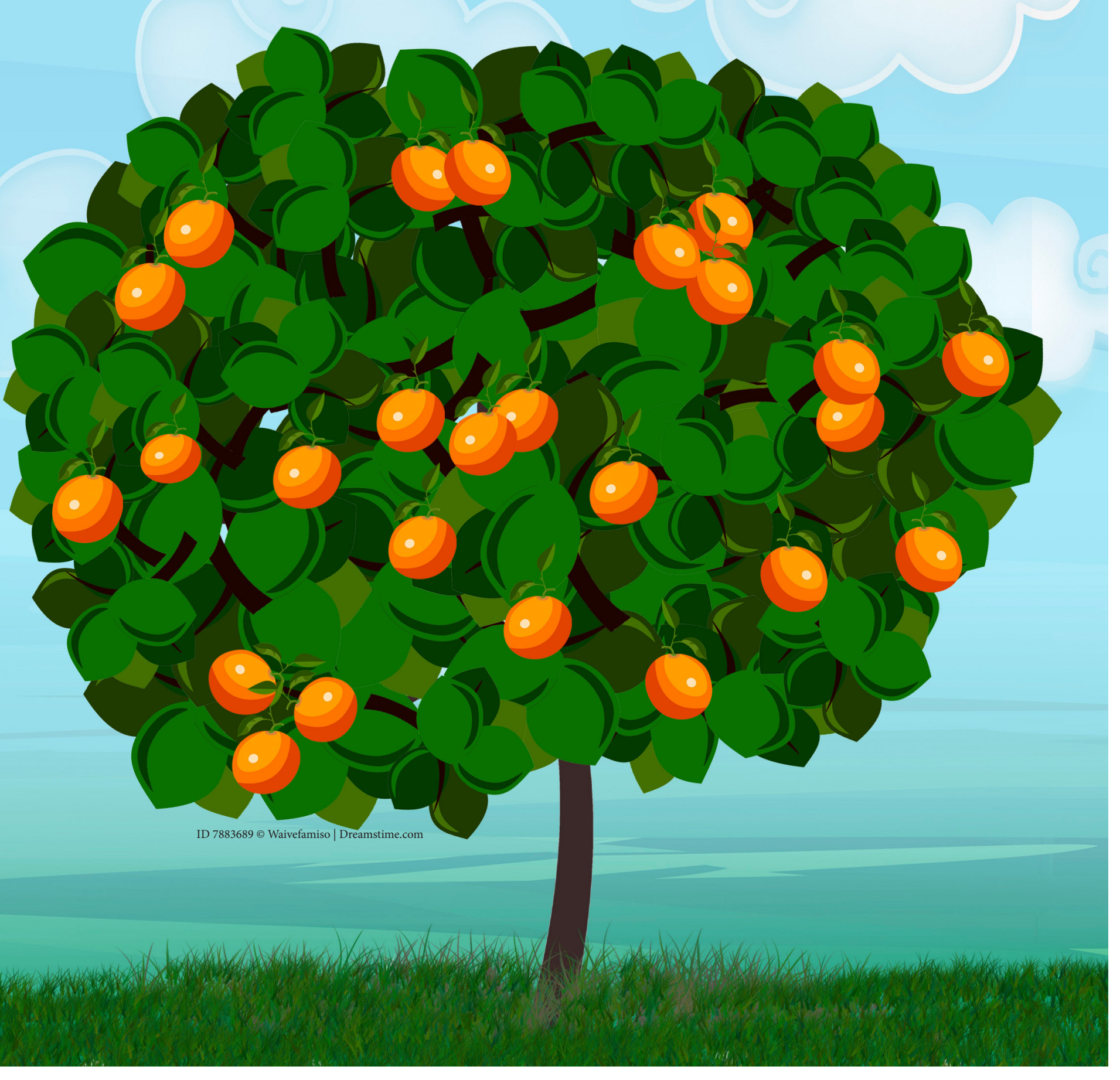

